\title{
Conjugalities and sexualities in conflict: monogamy and polyamory among LGBT groups
}

\author{
Antonio Cerdeira Pilão'
}

'Universidade de São Paulo, Programa de Pós-Graduação em Antropologia Social, São Paulo/SP, Brasil

\begin{abstract}
This article analyses how monogamy, polyamory and other forms of non-monogamy are displayed, interpreted and debated among LGBT groups. Is there a defence of affective and sexual multiplicity or does an endorsement of monogamy predominate, in order to claim greater legitimacy? The study was conducted between 2012 and 2017, based on ethnographic research carried out with virtual LGBT groups. I argue that there is no consensus that monogamy is an oppressive norm analogous to heteronormativity among lesbians, gays, and bisexuals, nor that polyamory is their ideal model for overcoming it. Through this study, I contribute to the understanding of the moral conflicts developed in the field of 'sexual politics' in contemporary Brazil.
\end{abstract}

Keywords: Lesbians, Gays, Bisexuals, Monogamy, Polyamory. 


\section{Conjugalidades e sexualidades em disputa: monogamia e poliamor em grupos LGBT}

\section{Resumo}

Este artigo analisa como a monogamia, o poliamor e outras formas de não-monogamia são apresentados, interpretados e debatidos em grupos LGBT. Haveria uma defesa da multiplicidade afetiva e sexual ou predominaria o endosso da monogamia, de modo a pleitear maior legitimidade? A investigação foi conduzida, entre 2012 e 2017, a partir de pesquisa etnográfica em grupos virtuais LGBT. Argumenta-se que não há consenso entre lésbicas, gays e bissexuais de que a monogamia é uma norma opressora análoga à heteronormatividade e de que o poliamor é o seu modelo ideal de superação. Por meio deste estudo, procura-se contribuir para a compreensão das disputas morais que têm sido desenvolvidas no campo das "políticas sexuais" no Brasil contemporâneo.

Palavras-chave: lésbicas, gays, bissexuais, monogamia, poliamor. 


\title{
Conjugalities and sexualities in conflict: monogamy and polyamory among LGBT groups
}

\author{
Antonio Cerdeira Pilão
}

\section{Introduction}

This article shares some of the results of my doctoral thesis in anthropology (Pilão, 2017) concerning the construction of a public debate on polyamory in Brazil. It analyses how LGBT ${ }^{1}$ groups display, interpret, and debate the issue of sexual-affective exclusivity. Do we encounter a defence of the need to overcome monogamy? Or do we find a tendency to disengage from the struggle for non-monogamy as a strategy for claiming greater legitimacy and respectability? What is specific in how lesbians, gays, and bisexuals represent monogamy and its alternatives? Does 'polyamory' feature as a relevant category and a desirable model of conjugality?

'Polyamory' is a term coined in the Unites States during the 199os to refer to the possibility for establishing multiple consensual and egalitarian sexual-affective relationships (Cardoso, 2010; Pilão and Goldenberg, 2012; Vaz da Silva, 2017). Unlike an 'open relationship' or 'swinging', it is a form of non-monogamy that not only admits a multiplicity of sexual partnerships, but includes the possibility of loving more than one person and sustaining more than one relationship at the same time (Klesse, 2006; Pilão, 2013; Silvério, 2018).

During my research with polyamorists, I took note of their admiration for the LGBT movement, and recorded many statements affirming that it is a success story of a collective confrontation of an oppressive social structure in the sphere of sexuality. It is thus not uncommon for polyamorists to try and associate the struggle against heteronormativity with a challenge to the monogamous norm, a fact that has also been noted by researchers working outside of the Brazilian context (Cardoso, 2014; Aviram and Leachman 2015; Colling, 2015; Silvério, 2018). Considering the relevance of LGBT agendas in the non-monogamous scene ${ }^{2}$, in particular the right to same-sex civil marriage, I here investigate its converse; that is, how gays, lesbians, and bisexuals approach the matter of monogamy. I ask to what extent non-monogamous conjugalities are deemed worthy of full citizenship, or how they may even be preferable to monogamy.

The article is part of a series of studies that focus on the 'construction of citizenship' for 'non-normative' sexualities and expressions of gender (Simões and Carrara 2014). It begins by considering a debate which is still incipient in the Brazilian social sciences, concerning the role played by forms of conjugality that differ from the monogamous, heterosexual and reproductive model. Through this study, I hope to contribute to an understanding of the moral conflicts that have emerged in the field of 'sexual politics' (Weeks, 1989; Facchini et al., 2013; Carrara, 2015) in contemporary Brazil, taking into account the controversial legal matter of the recognition of non-monogamous relations as family-like entities (Santiago Silva, 2014; Porto, 2018; Pilão, 2020).

The research was conducted from 2015 to 2017 by the Sexualidades e conjugalidades não-monogâmicas (NonMonogamous Sexualities and Conjugalities) Research Group, linked to the Núcleo de Estudos de Sexualidade e Gênero da Universidade Federal do Rio de Janeiro (Nucleus for the Study of Sexuality and Gender of the Federal University of Rio de Janeiro - NESEG-UFRJ). Virtual LGBT groups were chosen for analysis because

1 Lesbians, Gays, Bisexuals, and Transgenders. Due to lack of space, I focus only on identities related to sexual orientation. In a future article I will explore the specificities of 'trans' peoples' experiences and perceptions of polyamory and monogamy.

2 In Brazil, the advent of the visibility of Relações Livres (RLi, 'Free Relations') (Barbosa, 2011; Bornia Junior, 2018) saw the spread of the use of the category of 'non-monogamy' as a substitute for 'polyamory', since it is more comprehensive and does not put the affective dimension over the sexual. Thus, 'non-monogamous field' refers to a set of groups and social networks, both online and offline, that gather people who are interested in nonexclusive relations. 
they constituted numerous and active spaces with an intense exchange of messages, linking people up across Brazil. We carried out an observational 'netnography' (Kozinets, 2010; Bowler, 2010), without direct interaction with participants, restricting ourselves to published content. We did not analyse the profile of the posters or their sexual-affective biographies, focusing only on their arguments, opinions, and views on the theme during ongoing online debates. This article therefore investigates the moral conflicts and dilemmas surrounding monogamy, polyamory, and other forms of non-monogamy among a varied set of subjects who identify as gays, lesbians, and bisexuals in social networks ${ }^{3}$.

Research began with a survey of the most numerous Brazilian LGBT groups on Facebook ${ }^{4}$. Since these groups were mostly composed of gay people, we expanded to include groups that were composed exclusively of lesbians $s^{5}$ and bisexuals $s^{6}$. The research also included gay and lesbian groups that were specifically concerned with non-monogamous relationships ${ }^{7}$, as well as posts in other websites ${ }^{8}$ which were read and debated in these groups. Analyses are restricted to publications that refer to monogamy and/or polyamory, honing in on recurring issues, controversies and specificities. The messages that provided data for the analysis were published between 2012 and 2017. To preserve anonymity, the names of all authors have been omitted.

The article is divided into three parts, each concerned with one of the main discussions sustained by, respectively, lesbians, gays, and bisexuals. In the first part I show how sexual-affective freedom and the defining structure of a relation (monogamous or otherwise) are seen by lesbians to be less relevant than other issues, such as dialogue, honesty, and care between partners. I then draw attention to the fact that, for gays, monogamy (in opposition to so-called 'promiscuity') is more concerned with the search for multiple sexual partners than for multiple amorous relationships. Finally, I look at how bisexuals reject claims that they are unable to live monogamously, and how this can lead to a broader rejection of any association of bisexuality with polyamory and other forms of non-monogamy.

\section{Lesbians: honesty and care between partners}

Muniz (1992) and Heilborn (1992) argue that one of the distinctive features of lesbianism is the construal of love in opposition to reason or sex, which are comparatively less prominent in their rhetoric. According to Heilborn, this characterization suffuses the imagery of lesbians, and, depending on context, is explicitly endorsed. The author thus sustains that conjugality between women is characterized by long-lasting bonds directed toward 'care' and 'affective investiture' when compared to men, where it is mostly characterized by 'enjoyment', focusing less on companionship and placing greater value on the erotic dimension.

These views assist us in understanding representations of conjugality among the lesbian groups that I studied, which stress the maintenance of stable, profound and honest relationships. Unlike gays, who, we will see shortly, criticize monogamy via a defence of multiple sexual experiences with no affective content, lesbians are prone to think of the construction of consensual sexual-affective relationships with more than one person at the same time.

\footnotetext{
These categories do not exhaust all of the identities that interlocutors claim; viado (fag), sapatão (dyke), and pansexual are also commonly claimed in the field under analysis.

The groups studied were: 'LGBT Brasil', 'LGBT BRASIL', 'Brasil lgbt' and 'Brasil LGBT'.

The groups studied were: 'Sapatão do Momento' (Dykes of the Moment), 'Porra Sapatão' (Damn, Dyke) and 'Poxa Sapatão' (Hell, Dyke).

The groups studied were: 'Bi-sides', 'Bi-militância' (Bi-Militancy), 'Bi-girls' and ‘Guarda-sol' (Umbrella).

These were: 'Não-monogamia Lésbica' (Lesbian Non-Monogamy) and 'Poliamor gay' (Gay Polyamory).

Among which: Sapatomica.com, http://www.bisides.com/ and https://igay.ig.com.br.
} 
In the first publication to mention polyamory in the website 'Sapatomica.com', called 'Stop being the lover', the condemnation of the 'lover', who is considered to be a secondary, used, and neglected woman, is attenuated by the recognition of polyamorous setups. The publication touches on relations of infidelity and encourages women who have been betrayed to leave their unfaithful partner. In what pertains to the present discussion, the visibility of polyamory allows the break with monogamous exclusivity to also be construed as a deal:

"STOP EVERYTHING! Unless the person proposes a polyamorous relationship, in which all parts know about each other and accept it, You can't be with someone when you're always second best, who you can't even go out with, not even as friends." (10-01-2014)

It is as if polyamory neutralizes the negativity attributed to extra-conjugal ties, creating a break with the premiss that having more than one relationship necessarily implies in dishonesty. Even the very possibility of being an affective 'second choice' comes to be countenanced, so long as it is consensual. Thus, in a context in which polyamory is an option, the moral defence of monogamous fidelity is not absolute. What these monogamous and polyamorous moralities share is an affirmation of 'honesty' between partners as the condition for a dignified and legitimate conjugal relationship.

In one of the groups researched, a debate emerged involving a woman who was in a relationship with more than one person. What was roundly disapproved was unfaithfulness, so that many interlocutors suggested an open or polyamorous relationship as an alternative: "If it was a polyamorous relationship between the $4 \mathrm{grt}$, but if they don't know I don't agree"; "it's one thing if all parties are aware of eurth it's another to cheat"; "If all are followers of free love, what's the prob? We have to break paradigms and accept existing varied forms of love."; "Polyamory, free love, or open relationship is better than cheating on someone you love. The main thing is to be honest".

Before the approval of civil unions between same-sex people, in a context in which there were no formal institutions for lesbian relationships, Carvalho (1995) argues that honesty was the central guarantee for maintaining the relationship. Betrayals were thus often discovered, considering the efforts at transparency that permeates these unions. The author argues that there are two reasons for this: not only is honesty actively promoted by the parties in a relationship, it is also much more difficult to lie to a woman, as expressed by one of her interviewees: “with women you can't have any secrets, a woman knows everything, understands everything, wants to know everything" (Carvalho, 1995: 151).

Most of the women Carvalho interviewed prefer 'closed' relationships, without any overture to triangular or plural arrangements, in the belief that it is not worth risking the main relationship. Similarly, Vencato (2005) considers serial endogamous monogamy - successive relationships within a same group of people - to be an inclination among lesbians. The subjects of my research also claimed, on many occasions, to prefer monogamy, refusing non-monogamous relationships: "I am monogamous and would not live in a polyamorous relationship"; "No, thank you, you're welcome. I like monogamy"; "In brief: it's not for me LOL"; "Never been in one, no desire to be in one". Others say that they have participated in such relationships, but felt frustrated by them: "My feelings on open relationships can be summed up in one word: trauma"; "I was in one and it murdered my sanity".

Even if monogamy remains hegemonic, the last few years have seen an intensification of debates on alternative forms of conjugality. In this sense, there has been a call to recognize and explain monogamy, whereas previously it had not been a subject of debate.This can be seen in the group 'PoxaSapatão ${ }^{10}$, with four topics discussing non-monogamous relationships between June and July 2015, in contrast to the previous year when neither monogamy nor polyamory were discussed. According to Toledo and Filho (2012: 96), this recent growth in narratives that favour non-monogamy has mostly centred on young lesbians:

9 Sapatomica.com, maintained by three women aged between 22 and 24 years, was described in 2015 as the greatest blog for lesbians in Brazil. At present it is inactive, appearing only as a Facebook page, in YouTube and in Instagram.

10 'PoxaSapatão' was created on the 7th of June 2014. On the 1oth of October 2015 it had 2,310 members; on the 5th of May 2020 it had 54,369 members. 
"Women roughly between 19 and 25 years of age have a more flexible outlook on pre-established social norms in comparison to those in their 40 s or over. One difference among interviewees is that those between 18 and 25 years of age expressed greater acceptance of diverse ways of experiencing less traditional sexualities - non-monogamy, open relationships [...]”.

In the groups I studied, the recent visibility of non-monogamous practices is reflected in expressions of admiration for polyamory, and a desirability for partners that allow for other sexual-affective experiences: "I think it's $v$ selfish to think that one person can satisfy all your needs and to close yourself only for that person"; "I think monogamous marriage is one of the more difficult standards to be broken which society imposes! I am in favour of and would assume an open relationship with no problem..."; "I think it's a very beautiful thing! That you open up until you understand that your partner can and SHOULD be happy with people other than you (despite sexual relations, I'm talking of love)"; "I believe in polyamory. I also think polyamory is $v$ much more honest than many monogamous relations fed on betrayals"; "What a relief girls. LOL. I thought I was the only one with that view! I could never understand why we make even love into a prison!"

It is noteworthy that when polyamory or open relationships are rejected, the reasons offered tend to not refer to an intrinsic adversity of these forms of conjugality, in contrast to monogamy which is often presented as being repressive. Personal inadequacies are thus recognized (particularly those linked to feelings of 'possession' and 'clinginess'), revealing shortcomings in terms of a modality of relating that is seen to be more 'evolved': "I admire people who can live in polyamory. I can't"; "I'm not evolved to that point yet"; "Something for people who possess a super evolved self-knowledge and an excess of emotional intelligence; in other words, not for me"; "I'm too possessive for these things!"; "I would well like to control my clinginess or unclinginess to be able to do something like that [...] I envy, cuz look... I even cling to my bedsheet and keep spying on it on the clothesline to see if anyone touches it LOL" [my emphases]

The majority of my research subjects do not condemn monogamy. A relationship can be monogamous or not; what matters is not sexual freedom, but care, dialogue, honesty and consensus. Even in a group for nonmonogamous lesbians ${ }^{11}$, an emphasis on freedom is attenuated by a concern for the feelings of one's partners. Instead of insisting on the need to accept this freedom, participants admit that they are more committed to mutual care, letting go of their autonomy in accordance with the limits and sufferings of their partners:

"Girls, what is freedom? For me freedom is to be guaranteed my emotional integrity, to be respected, it is active and constantly constructed consensus, mutuality, reciprocal respect... empathy, non-objectification, non-bulldozing. To rape is to run your desire over those of another. If free love occurs in a dynamic in which I'm running over the other, then it's not free, it's authoritarianism, it's aggression, it's silencing, it's further abuse of our bodies." (15/09/2014)

Non-monogamous lesbians thereby believe that freedom and its effects should be an object of discussion and reflection, aiming for a joint deconstruction of feelings that may compromise the quality of the relationship. Men are treated as antagonists, as 'affectively irresponsible' and ethically uncommitted. The idea of recreating non-monogamy from a feminist perspective is thus posited; a non-monogamy that would not prioritize a liberal political freedom as men are said to do when they hold their female partners to account for feeling insecure. We find here a criticism of non-monogamous men, since, in the view of the lesbians I researched, they are not privy to a pact of mutuality, respect and empathy, placing greater value, instead, on a selfish freedom, devoid of care.

The association of men with irresponsibility, and even abuse, and with an inclination to impose their desires on women, is a point of contention between lesbian and bisexual women. In some cases, the former go as far as to question the participation of the latter in internet forums, claiming that they are not trustworthy for maintaining intimacy with oppressors. Bisexual women, in turn, accuse lesbians of biphobia. People often quit groups because of such conflicts.

11 Created in September of 2014. On the 10/10/2015 it had 241 members. On the 06/05/2020 it had 254 members. 
This controversy is also studied by Facchini (2004), who argues that lesbians see bisexuals as 'dirty' and potential vectors of disease because of their sexual relations with men, who, for their part, are seen to be necessarily promiscuous. Jaeger et al (2019) suggest that this disqualification of bisexuality feeds back as selfpraise, in the sense that only lesbian women are trustworthy. In this sense, the violence suffered by bisexuals is deemed to be misunderstood by lesbians, since the only suffering possible for bisexual women would be lesbophobia. Bisexuality is thus almost always construed as a joke, something to be despised, ignoring the suffering that stems from biphobia (Jaeger et al., 2019: 9).

Among the groups that I studied, lesbians who were positive about non-monogamous relationships were nonetheless largely resistant to the involvement of their partners with men. Some expressed disgust and the wish to keep clear from them: "People, you have no idea how much I hate men (I think you do, LOL). Fuck! And also, unfortunately, I get in a bad way when people disregard my horror of men". Another participant says that: "my lesbianism is not a sexual orientation, it is my radical political project which doesn't involve men and it's $v$ relevant to my life". Interactions with 'brocialists' or 'bronarchists', as many of the men who participate in the nonmonogamous field are known, is permeated by the protest that their sexual freedom harms, objectifies, and excludes. In some cases not being involved with men is therefore not enough; it is safer to not be involved with those who are involved with men.

This resistance to maintaining partnerships with women who have relationships with men can also be explained by a feeling of inferiority:

"We need to think about why lesbian girls have this problem, it's not because she wants this, it's because she's been led to this, we have always been made inferior by men and raised to feel inferior, when we get with a bi girl we get a little scared of not satisfying her, for example, and then she goes and also gets with men, like, it's violent for some girls, like 'I'm not able, as a woman, to satisfy another woman' [...] the problem is not with bi girls, but with the men and with patriarchy and in all of the oppression that she's already suffered by all of this, just because she doesn't have a dick - a man-dick, to not be transphobic" (24/10/2014)

This feeling of 'inferiority' is enhanced when non-monogamous men allow their partners to freely maintain relationships with other women but not with other men. One participant adds that these men only see lesbian women as fetishes, and do not believe in the viability of the love between two women. Another comment reveals indignation at the depreciation of the lesbian bond, which is interpreted as being a lesser relationship, an ephemeral amusement:

"Before anyone says I'm biphobic or that I'm disregarding polyamory: no, sis, what irritates me, in fact, is objectification, as if a lesbian relationship is nothing more than making out, a game. It irritates me. It irritates me a lot!" (13/06/2016)

We will shortly see that while there is an ideal of morality directed at monogamy and sexual self-control among gays, in lesbian groups it is honesty and consensuality that are more strongly valued. Sexual excess and promiscuity are thus not the main sources of controversy between women; rather, they see infidelity and affective responsibility as the true problems that need to be addressed. Hence the tendency for polyamory to be conceived of as a conjugal possibility in lesbian groups.

Despite their relative ubiquity and positive evaluation, certain obstacles to the construction of nonmonogamous relations emerge, particularly those related to insecurities deriving from 'sharing' their partners with men and male inferiorization of the bond between women. To guard against the 'contamination' generated by proximity with male sexuality, lesbians may avoid relationships with bisexual women. Strategies for contention, control, restriction, and refusal of male sexuality are clearly evident, revealing a perception of the danger associated with its autonomous and spontaneous exercise. 


\section{Gays: between monogamy and promiscuity}

Comparing the practices of heterosexual and homosexual men and women, Fry and MacRae (1983) note that we commonly find reflections on the benefits and disadvantages of having a single partner ('steady relationship'/marriage) or diversifying, choosing 'sexual adventures'. Among homosexuals and heterosexuals we find defenders of 'open marriages', of 'free love', or of 'traditional marriage': "But how could it be otherwise when both homosexuals and heterosexuals belong to the same society, thereby sharing the same culture?" (Fry and MacRae, 1983: 113).

The authors argue, nonetheless, that in the large cities the opportunities available to men for having noncommittal sexual interactions with other men are near infinite, and are therefore more common than among lesbians or heterosexuals:

"Someone once said that homosexuals are the only people who take sex seriously these days, since they function full time. Indeed, among men who participate in the homosexual scene, it sometimes seems to be almost a point of honour to not let any opportunity for a sexual relationship slip away, and this is a constant theme of conversation. Some give the impression that, for them, all men are possible partners". (Fry and MacRae, 1983: 108)

Similarly to Fry and MacRae, Heilborn (2004) states that it is in 'gay subculture' that we find the greatest propensity for multiple and anonymous relations, in contrast to heterosexual and lesbian conjugal partnerships which tend to be more fixed, intimate, and stable. As she notes, despite the fact that the HIV/AIDS epidemic of the end of the $2 \mathrm{O}^{\text {th }}$ Century contributed to a sexual life that was seen to be less 'permissive', not many gays adopted the model of a monogamous family and a stable conjugal life. While there was thus a tendency toward conjugality, the general tone still favoured a multiplicity of sexual partners and a lower propensity for longlasting and monogamous partnerships.

Among the gay subjects of the research, monogamy is contemplated, first and foremost, in opposition to 'promiscuity'. Debates on polyamory and non-monogamous arrangements are hence less common than in other LGBT groups. While some of the rhetoric points to a greater propensity for gays to have multiple sexual partners, supporting the interpretation of the authors quoted above, there is some suggestion that the number of sexual partners has nothing to do with sexual orientation. An article published in the IG Portal ${ }^{12}$, and widely disseminated among the groups I researched, points to an unequal treatment of gays and heterosexuals: "A gay commenting that a 'hunk' on the beach is hot may be sufficient to label him as promiscuous. A straight man who says that a woman sunbathing is hot is just taken to be a run-of-the-mill comment".

The article was hotly debated for opposing the view that gays are 'promiscuous', as this post makes evident:

"I think you wrote about Gays from the Wrong Planet. This is Earth. Not once did you mention the Gay Universe: Gay Clubs, Saunas, Gay Pride Parades, Hook-up Points - Thousands (in the Aterro do Flamengo, Shopping Mall Bathrooms, Bus Stations), Porno Cinemas, Hotels, and exclusive Ranches for Gay parties, Pool Party, Samba School Plazas, Carnival and so on. (notice that I'm only referring to Rio de Janeiro). Ah! Almost forgot to mention the hundreds of Thousands, perhaps Billions of 'Promiscuous sites' with Zillions of 'Amateur Gay' films, prostituting themselves with one, or dozens, or even hundreds of men and even with Animals, Disponivel.com, Manhunt.net, not to mention the hundreds of Fashionable Apps like Grind, Scruff... and so on. See how you don't need to write a Doctoral Thesis to know what everyone knows. This Small Sample is from Brazil, but unfortunately, this is a WORLDWIDE reality. So DON'T come and tell us that Gays are not Promiscuous. Lil' kisses for you!!!” (19/12/2015).

As well as disagreement on a purported prevalence of 'promiscuity' among gays, these debates also revealed a tendency to see promiscuity as intrinsically negative, a less dignified condition than monogamy.

12 Available in: https://igay.ig.com.br/2015-05-12/gays-sao-promiscuos-ator-reclama-da-repeticao-dessa-certeza-generalizada.html. (last accessed 06/05/2020). 
One post says that a multiplicity of sexual partners is an 'empty' and 'grotesque' reality which fails to distinguish men from animals: "we are just a piece of meat, where everyone can have a go". Another participant in the forum backs this view: "a relationship does indeed have to be monogamous [...] we should respect the other and respect ourselves, not put ourselves on display like meat at a butcher's".

In recent years, the right to a monogamous marriage has spearheaded the political agenda of the LGBT movement. For Vale de Almeida (2006), the struggle for this right aims to extend citizenship to non-heterosexuals, and does not necessarily imply in a positive view of the institution of monogamous marriage since, even with legal rights assured, some of those who fought for it would choose not to get married. Although the extension of full citizenship is premised on the possibility of monogamous marriage, and not its obligatoriness, I nonetheless noticed in the groups that I researched a critical stance towards those who do no exert their sexuality within the bounds of a stable and monogamous relationship.

The link between homosexuality and promiscuity feeds the fear that it be construed as an impure and undignified sexual orientation, whereas severing this link promotes hope for respect, establishing thus a distinction between 'good' (monogamous) homosexual relations and 'bad' (promiscuous) ones. Through recourse to monogamy, the negativity associated with homosexuality is deflected to those who lack self-control and who therefore do not limit the exercise of their sexuality to monogamy. In this sense, Seidman (2011) asserts that there is a model of homosexuality that excludes, segregates and represses hedonism and promiscuity, transferring the stigma of same-sex sexual practices to sexual acts not anchored in love and monogamy.

This 'anti-promiscuity' stance gained ground in the 1980s-1990s with the HIV-AIDS epidemic, winding back the changes that came in the wake of the 'sexual revolution', endorsing marriage and feeding a general mistrust of non-monogamous relations (Frank Furstenberg Junior, 1994; Bob Simpson, 1994; Meika Loe, 1998). The epidemic led the public to be more concerned with numbers of sexual partners (Joseph Catania et al., 1993; Gilbert Herdt et al., 1990) and with a pretence promiscuity among male homosexuals, which was seen to be a public health concern, subject to opinions in news outlets and object of scientific research (Cavalcanti, 1995; Heilborn, 2004; Facchini et al., 2013).

In this sense, Butler (2003: 239-240) claims that the recent turn toward gay marriage is a 'shamed' response to AIDS, condemning so-called promiscuity in order to project an image of health, normality, and the ability to constitute monogamous unions. For Miskolci (2007) the struggle for same-sex civil partnerships in Brazil led to a 'domestication' of the movement, which came to defend 'normalizing' and 'assimilationist' aims which emptied it of its potential to critique the social order. This fact resulted in cleavage between organized movements and a few dissonant voices that questioned whether the right to civil unions would be an actual achievement or a trap ${ }^{13}$.

The 'anti-promiscuity' view, endorsed by some of the subjects of my research, and challenged by these scholars, is also mocked in the groups I analysed. The critics argued that there is a contradiction in fighting for inclusion and diversity while upholding traditional norms and perpetuating sexual hierarchies, condemning as inferior those who do not conform to the 'heterosexual standard' of monogamy. Reprehending promiscuity meant preserving the notion that there are incorrect sexualities, invalidating other types of sexual-affective experiences:

"When are we going to stop fighting only for those who reproduce a heterosexual norm? When are we going to stop condoning the oppression endured by our 'promiscuous' brothers and sisters? When are we going to stop hiding behind 'love', pretending that sex doesn't matter?" (12/06/2016).

13 Similarly, Colling shows that during the approval of the law of equal marriages in Portugal there was a general fear that polyamorous themes would provide ammunition for the opposition. Refusing an association with non-monogamous agendas was seen to be a 'strategic' measure. This 'politics of the possible', defended by Miguel Vale do Almeida, among others, was harshly criticised by the Portuguese polyamorous movement, which glimpsed, within the 'possible', the limits imposed by heteronormativity (Colling, 2015: 97-8). 
Two texts ${ }^{14}$ which were debated in the groups I studied affirmed that the pro-monogamy rhetoric expressed a conservativism of the LGBT movement, incorporating the point of view of the oppressor and turning its back on historical victories for the protection of sexual liberties. Instead of fighting oppression, they would only reveal their own normality by way of monogamy, relegating to a second tier those whose sex life is considered excessive, such as those who attend gay saunas, take part in orgies, and polyamorists. Criticizing the 'assimilation' of the homosexual struggle by heterosexual society, these critics argue that it is not by 'cleansing' their relationships that the community will finally emancipate itself: "We don't need any politics of respect. YES we will have promiscuity! [...] YOU WILL NOT ASSIMILATE US!".

Recent decades have seen the proliferation of theoretical approaches to the simultaneity and inseparability between structure and history, reproduction and change, conservation and transformation (see Bourdieu, 1994; Sahlins, 2008, among many others). Confronting understandings of the dichotomy between 'assimilation' and 'resistance' in forms of activism, Ellen Lewin $(1998,2002)$ claims that resistance favours accommodations and that conformity depends on subversion ${ }^{15}$. Even if, from a theoretical point of view, it may be possible to assume a non-dichotomous position, rejecting the idea that a desire for monogamous homosexual marriages must be interpreted in terms of either 'assimilation' or 'resistance', in the groups I studied these polarities remains actively expressed.

Among the subjects of my research these positions tend to be seen as antagonistic, generating disputes over precedence. Thus, the incorporation of the model of monogamous marriage by homosexuals often falls into one of two explanatory extremes: it is seen to be either a submission to heteronormativity, thereby conserving oppressions and exclusions; or an indispensable tool for reform and the acquisition of full rights, respect and dignity. It is therefore evident that, for some, the goal is to be accepted in the heterosexual world, to be a part of society, with the same dreams and aspirations of love, family, marriage, and property. It is important to fight for these rights and to resist the image of promiscuity. For others, this goal of acceptance is 'assimilationist', and being included in an oppressive and castrating social order is tantamount to perpetuating oppression and repression. It must thus be rejected.

When the implications of the political and moral promotion of monogamous marriage are contested, polyamory emerges as a possibility and an issue. However, as I have shown, there is a tendency for gays to erase this term and, as a consequence, to evade the very view that it is possible and desirable to love more than one person at the same time. Debates surrounding non-monogamy are thus more inclined to be framed as a desire for multiple sexual partners than for an amorous multiplicity. This is even the case where the term 'polyamory' is evident, such as the group 'gay polyamory' ${ }^{16}$, in which most messages seek out partners by focusing on the erotic dimension: "Couple for 9 years. 31 and 34 years of age [...] We dispense those who are only passive or only active and the curious"; "I am a discrete passive [...] I don't care about looks, I only ask for discretion"; "I am a passive non-effeminate gay [...] I like active guys ... Ages 18 to 42..."; "I AM LOOKING FOR TWO HUSBANDS!!! (ACTIVE OR VERSATILE, 25 to 45 years of age) [...]".

Eroticization is accompanied by tensions, which are evident at the outset, in the very description of the group: "Group for followers of POLYAMORY, but do not mix POLYAMORY with libertinism or promiscuity". Many of the messages in the group furthermore reveal discomfort with this association, seeking to guard polyamory against accusations of promiscuity: "Some people mix up Polyamory with [...] orgy, ménage, etc. They say that they want a poly relationship... but post pictures in their underwear, eroticized [...]"; "Polyamory is a ramification of

\footnotetext{
14 Available in: http://nossostons.blogspot.com/2012/o5/promiscuidade-de-cu-e-rola.html and in: https://jornalggn.com.br/noticia/machos-ativoscomedores-as-passivas-promiscuidade-e-o-medo-de-amar/. (last accessed on: 05/05/2020).

15 The author uses the concept of 'invented traditions' to refer to how the reproduction of marriage rituals by homosexual couples results in its renovation. 'Tradition' is thereby replicated, generating continuity and coherence, while also being marked by an original appropriation.

16 The 'poliamor gay' group was created on the 30 th of December 2014. On the 6th of May 2020 it had 1858 members.
} 
a serious relationship [...] it's not something you find in an ad [...]"; "The hardest thing is finding someone who doesn't confuse polyamory and debauchery! [...]"; "Polyamory happens when someone is capable of truly loving more than one person, do not mix polyamory up with SLEEPING AROUND."; “just hooking up, sex for sex's sake. But unfortunately that's the first thing that comes to the minds of many when I say polyamory, it's a sad fact".

Rejection, even dread, of promiscuity is materialized in the defence of both monogamy and polyamory, to the degree that love (whether for one person or more people) is seen to be a more noble sentiment, capable of purifying sex. However, polyamory reveals itself to be ambiguous, sometimes being defined in opposition to promiscuity and, yet, at other times, as referring strictly or primarily to sexual interactions. As a result, some of the members of 'gay polyamory' are critical of messages with erotic content, aiming to support the 'seriousness' of polyamory by dissociating it from promiscuity. In this way, polyamory is approximated to monogamy, validating its emphasis on love and conjugality while criticizing the importance accorded to eroticism and sexual pleasure.

Some of the subjects of the research lament this 'anti-promiscuity' crusade: "They want to sneak into polyamory the same square and restricting moralism present in traditional relationships"; "They make orgies out to be something disrespectful, criminalize relations that are based only on sex, as if there were something wrong in that"; "It's easy to do that after a bunch of crazy fags put their necks on the line, sometimes dying fighting for us to have a modicum of freedom and then come on the internet and tell others what to do".

The most fundamental notion to emerge from debates on conjugality among gays is 'promiscuity', which takes on a diffuse, general, and pathologizing meaning, as casual, multiple sex, devoid of affective/subjective involvement. As an 'umbrella term' used to express a binary logic, promiscuity gathers the power to deny monogamy, which becomes its opposite. Among the consequences is that other categories which indicate alternative conjugalities, such as polyamory, open relationship, swinging, relações livres (free relations), and relationship anarchy, are rendered invisible.

The neglect of the contrasts between sexual-affective practices is evident in the propensity to leave them unnamed and unindividualized, so that they become subsumed under the air of totality that 'promiscuity' assumes. Although they are recognized, as I have shown for 'polyamory', there is a widespread suspicion that, in the end, they have the same meaning as 'promiscuity'. Both monogamy and that which escapes it are homogenized, blurring other possible borders, which lose their ability to multiply and differentiate sexual-affective arrangements. As the antagonism between promiscuity and monogamy hardens, it becomes increasingly more difficult to confer legitimacy to 'loveless' sex, or to think of love outside of the confines of an exclusive and dyadic relationship.

\section{Bisexuals: invisibility and 'fetishization'}

As Lewis (2012) stresses, bisexuality is widely assumed to be a transitional phase, or a lack of nerves in coming out as homosexual. The belief that a 'true' sexuality will at some point prevail is proof of an understanding of bisexuality as an indecision, a non-place, or as a flux toward one of the unquestionable and stable extremes of the 'homo'|'hetero' binary. In the groups that were part of my research, these representations are a source of discomfort, generating an effacement of bisexuality, since they consider that, in the final analysis, everyone is monosexual - that is, exclusively "hetero" or "homo".

The invisibility of bisexuality also leads to the view that true sexuality can only be revealed by the gender/ sex of one's partner. In contrast, the bisexuals who are part of this research define sexual orientation not through the sex/gender of the person they are involved with at a given moment, but by desires that are built 
up throughout their lives. Current relationships are hence not definitive of one's sexual orientation, so that a woman would not cease to be bisexual for being in a monogamous relationship with a man, nor would she be a lesbian if this relationship were with another woman.

When bisexuals strive to carve some visibility and recognition, so that their sexual orientation is not reduced to a phase or indecision, they are almost necessarily treated as being non-monogamous and/or promiscuous. This characterization generates profound discomfort, since bisexuals are seen to be incapable of living with a single person. The allegation is that, as bisexuals are interested in people of both genders, when they are in a relationship they have to suppress their desire for the absent gender ${ }^{17}$.

Some studies do indeed suggest a correlation between bisexuality and non-monogamy, concluding that there is a tendency for bisexuals to adopt arrangements that do not demand sexual-affective exclusivity (Rust, 1996; Page, 2004; Sheff, 2005; Wosick-Correa, 2010). In contrast, in the groups I studied, this connection is frowned upon. It is alleged that having desires for more than one person is universal, and not a reality circumscribed to bisexuals. Therefore, the fact that some people do not limit their partners by gender does not make them more or less inclined to monogamy.

It is thereby argued that bisexuals can be monogamous like any monosexual person, so that they do not need to be simultaneously involved with men and women: "I don't need a polyamorous relationship to experience my bisexuality" (woman); "I'm bi and I'm very happy in my monogamous relationship" (man); "I never see myself as monogamous nor as non-monogamous, I've had both types of relationships, but I never 'missed' going out with people of the other gender" (woman); "Look, I don't know about you guys, but I love people. Their gender matters little to me." (woman); "I don't think people should associate sexual orientation with ways of relating. In fact, I believe that only reinforces bi-phobic stereotypes and stigmas, like 'all bis are polyamorists' [...]" (woman).

Despite the predominance of messages expressing discomfort with the association of bisexuality with non-monogamy, coming primarily from monogamous people, there are also those that express frustration with not being able to have relationships with men and women at the same time: "I'm non-monogamous and I don't feel complete unless I can be with both genders..." (man); "I disagree with those who are saying that sexual orientation doesn't make a difference [...] When I was monogamous, it sometimes made me sad to know that, if I stayed in the relationship with my boyfriend at the time, I would never experience a relationship with a woman" (woman); "it's a FACT and respect for the existence of others to admit that some bi people feel dissatisfied in monogamous relationships because they miss other gender/bodies" (man).

Unlike polyamorists, who identify an intersection between bisexuality and polyamory, placing value on the fact that both enable a widening of amorous possibilities (Pilão, 2012), in the groups researched this connection is seen as incidental and idiosyncratic and not as an inclination that all bisexual should share. The ensuing need to ratify the possibility of monogamy among bisexuals is sometimes thereby converted into a refusal of any association with non-monogamous relations, as if these would be capable of disqualifying bisexuality.

In other cases, the association is not seen to be intrinsically negative, although there is a recognition that it can reinforce the idea of an interdependence between the two. Faced with this possibility, most arguments are directed against a reduction of bisexuality to debates on non-monogamous relationships rather than on their outright rejection. The main point is that, in seeking to affirm the autonomy of bisexual identity, claiming the same legitimacy and visibility as homo/heterosexuality, bisexuals tend to condemn straightforward links between bisexuality and a type of conjugality.

When this aim is converted into a defence of monogamy, some messages tend to reveal disapproval: "we have to be concerned so that our final goal is not assimilated to the traditional values of society, contributing to a tidy

17 There are differences among bisexuals regarding the binarism of gender. It is not uncommon to hear, in these circles, that there is a multiplicity of genders, with possible transitions and ambiguities. At any rate, the accusation being considered here comes from a binary premiss, dividing people into 'male' and 'female'. 
bisexuality, while those who are confused, non-mono, those who want to be promiscuous, are tossed in the bin" (man); "It's that idea that we have to look 'tidy'. Like, it's OK for you to be bi, but you have to be monogamous. [...]" (woman). In contradistinction to the gay movement, which is interpreted as being 'assimilated' by the monogamous norm, they defend an activism that moves away from the 'conservative standard':

"DON'T reify this normative message that 'we are not confused, we don't want ménages, we are not non-monogamous'. YESSSSS WE ARE, WE ARE ALL OF THIS, we have a right to all of this. Homosexuality is being accepted at the cost of being assimilated, of not breaking away, of emulating all of the 'traditional values' of the patriarchy and of heterosexuality. WE WILL NOT CONTRIBUTE TO THAT and create a bisexual normativity, plz., let's build a badass movement that breaks away and frees, that criticizes the policing of the sexuality of people. I'm counting on you assholes." (Man, 03/04/2016).

In contrast to gay groups, in which polyamory features little, or lesbian groups, in which it has some relevance, polyamory is clearly important to bisexuals. Thus in 'Bi-sides' ${ }^{18}$, the most numerous Portugueselanguage bisexual group in Facebook, there are dozens of topics discussing polyamory and hundreds of messages reflecting on the connections between bisexuality and non-monogamous relations. It is noteworthy that a number of publications specifically focus on the role of bisexual women in these relationships - indeed there are groups exclusively for bisexual women ${ }^{19}$ - which contrasts with a certain lack of reflection on male bisexuality and polyamory. This tendency is evident in a message written by a man: "Why are poly relationship always of Women, Woman and Man [?] I'm Bi and can't find a relationship between two Men and a Woman"2."

Although polyamory has more enthusiasts among the bisexual women I researched, there are also critiques of the non-monogamous scene, claiming that they are treated as objects for 'sexual consumption', 'fresh meat for the slaughter', and 'unicorns ${ }^{21}$. The 'high value' that non-monogamists place on bisexual women is thus perceived as a 'fetishization' (Rust, 1996; Ritchie e Barker 2007; Bornia Junior, 2018) by cisgender and heterosexual $m^{22}$ with the consent of their partners. Along with invitations for threesomes exclusively with women, they are also accused of constraining their partners to only enter relationships with other women:

"[...] in relationship with cis men, please be patient... they always fetishize, it makes me so angry, it really gets on my nerves, either the guy proposes a ménage or says that I can hook up with or have relationships only with women, which is not cool, as if a relationship with a woman is somehow lesser to the extent that it does not cause insecurity in him... and damn it, I mean, even considering the fact that I prefer women, situations like this always happen in relationships with cis men" (27/01/2015)

As this quote makes clear, it is not uncommon for bisexual women to declare that they want extra-conjugal relationships or threesomes only, or mainly, with other women. In spite of this, faced with their male partners disapproval of relationships with other men, bisexual women rarely interpret this as choice or an orientation, but as male demand and oppression: "you know what this's called? Chauvinism and objectification [...]"; "More than fetishism. It's phallocentric. This idea that not having a dick makes the person less interesting. As if a dick were this wonderful golden object, which no one can live without."; "I don't know how some women can close their eyes to this and say that it's ok. People wake up! Your men are assholes and they're so good at it that you even think it's cute".

18 On the 4th of August 2015, Bi-sides had 1,173 members. On the 11th of May 2020, it had 4,919 members. The group also has a website (http://www.bisides. $\mathrm{com} /$ ), where it proclaims that its aim is to consolidate a nationwide activism, promoting on-site activities and internet forums.

19 One of these groups was announced in Bi-sides: "Secret group (Bi / Polyamory for women). For those who feel a lack of accepting places with political compromise and sorority for bi and polyamorist women...”. Various replies welcomed the group: "Waaaaant!"; "Toss me in that!"; "I'm in"; "Put me plz"; "Need it"; "Want it! Necessary", etc.

20 Bisexual men not only lack exclusive groups, they are also much less numerous in the non-monogamous scene than bisexual women (Pilão, 2012). They are sometimes assumed to be inexistent, rare or invisible (Veaux e Rickert, 2014; Silvério 2018).

21 According to Silvério (2018: 58), the term 'unicorn' captures the rarity of women who are willing to be in relationships in which they are content to fulfil only the wishes of the couple, without any need to have their own desires satisfied. According to Bornia Junior (2018: 34), the term can be used to express the idea that the consensual and symmetrical inclusion of a woman in the desires of a couple is a myth, like the unicorn.

22 'Cisgender', or 'cis', refers to people who identify with the gender that they were attributed at birth; that is, those who are not transgender. 
The view of these relationships as objectifying and fetishizing is also the subject of critiques and reflections, with some bisexual women arguing that their male partners are different: "My relationship does not fit into that type and [my partner] is mega careful to not come off as if he 'has a good thing going' or as if it's all about him."; "It has nothing to do with fetishization, he doesn't take part in anything, doesn't see anything, doesn't try to put himself in-between as other straight guys who date bis do". Some women even state that the deal is symmetrical, to the extent that they also ask that their male partners not get involved with other women: "With another women I'll be insecure because I can also provide the same thing she can [...]"; "For me it's all about ego, as bad as that may sound. She's got what I got, what if she's better?"; "I wouldn't accept it if he got with another woman, because he's already got my pussy".

Even if some bisexual women do not see themselves as submissive, there is a suspicion in the groups I studied that they are oppressed to the extent that non-monogamous practices involving cisgender men tend to be conceived as mostly meeting the latter's needs. Bisexual women's desire to have relationships with women can hence be seen as an aspect of male domination, raising doubts about their own autonomy, or else seeing other women as subjected, silenced, constrained. Some members of these groups thus question the participation of bisexual women in these relationships, interpreting it as an imposition of their male partners:

"All we see is straight men speaking for the girl and this creates a really bad vibe! I used Tinder recently and spoke to a bunch of couples and this was always my feeling, I wanted to say MAN SHUT UP, LET THE GIRL SPEAK TO ME AS WELL. Now I'm always on the lookout that the girl is not into it but is being influenced by the guy" (18/10/2014)

There is thus a set of views on the dangers of non-monogamous relationships with men, which see the latter's desire for 'openness' as perhaps compromising the freedom and dignity of women. This view inevitably recalls a feminist position, which reached its peak in the 1980's, according to which, as Rubin (1984) observes, 'sexual freedom' emerges as a way of objectifying women and perpetuating male privilege.

On this matter, Gregori (2003: 101-102) claims that feminist anti-sex moralism, promoted by 'radical feminism', rejected heterosexual sex not only on the basis of desire, but as the consequence of a particularly deterministic interpretation of the power dynamics of heterosexual relationships. In light of this, practices as diverse as pornography, sadomasochism, prostitution, and sexual promiscuity are interpreted as manifestations of violence, and a danger to women.

It is possible to say that the critiques of non-monogamous relationships are focused mostly on the role played by heterosexual cis men, who are singled out as being responsible for the suffering of bisexual women ${ }^{23}$. Thus the freedom promoted by polyamory may be considered illusory, dangerous and perverse, coercing women to act in accordance with male expectations. It is furthermore important to reiterate that the subjects of my research constantly face the dilemma of having to choose between criticism of the monogamous norm or the presupposition that they are polyamorous and, therefore, incapable of practicing monogamy.

\section{Concluding remarks}

As Foucault (1976) argues, the fact that monogamy became the structuring element of marriage, family and the expression of legitimate sexuality in the West between the $18^{\text {th }}$ and $19^{\text {th }}$ centuries strengthened its naturalization, so that it was no longer necessary to formulate it or even name it. The 'silent' or 'discrete' reality of monogamy operates much like Latour's (2000) 'black box', in that its context of elaboration is effaced so that it may emerge as an unquestionable truth.

23 The depreciation of cismasculinity is also reflected in the resistance that 'bi' women say they suffer from lesbians, as if they were ambiguous, less trustworthy and dangerous for maintaining relations with the oppressors. Its negativity would thus overflow their bodies and identities, reaching all women who are seen to be submitted to their desires. 
Analysing how polyamory is received and interpreted in LGBT groups, I have sought to contribute to overcoming the erasure and invisibility of contemporary reflections on monogamy in studies of gender and sexuality. By opening the 'black box' of monogamy, our gaze is no longer restricted to behaviours considered 'aberrant' or 'deviant', including the hegemonic structure of conjugality, the 'natural' form that need not be explained or uttered, the only legal model of marriage in the West.

The polyamory debate, which intensified in Brazil during recent years with controversies concerning 'polyaffective' civil unions (Pilão, 2020), has laid the groundwork for monogamy to be more explicitly recognized, named, and examined, inviting agents to take a stand regarding a theme that was not previously an object of consideration. Although polyamorists understand monogamous and heterosexual norms to be complementary, I have shown divergences among lesbians, gays, and bisexuals.

My study has revealed that the central interest of gays lies in the struggle for the right to monogamous marriages. This has led to a depreciation of sexual promiscuity, which is seen as an obstacle to obtaining respect. Against the tide of endorsing monogamy, we find a defence of 'sexual liberty' and of so-called 'promiscuity', with the matter of amorous multiplicity rarely emerging at all.

In lesbian groups we encounter an emphasis on dialogue, honesty, and care between partners, along with a desire to break with what they perceive as a (male) logic that privileges freedom over affective responsibility. Here polyamory can be as legitimate as monogamy, so long as relationships with bisexual women are avoided, because the latter are seen to be subordinate to interests of men, accomplices to male domination.

Among bisexuals, the reduction of bisexuality to non-monogamy is seen as a barrier to a process of claiming a specific identity. The need to show that sexual orientation is independent of any conjugal arrangement results in two attitudes: one considers that monogamy and polyamory are equally possible for bisexuals; another, seeking to prove that bisexuals can also be monogamous, criticizes any link between polyamory and bisexuality.

A shared theme among lesbians, gays and bisexuals is the need to deal with accusations of being incapable of love and of building solid unions. Thus, bonds between women are seen to be less relevant, relations between men are seen to be purely sexual, and bisexual people are considered to be unable to commit to a single partner. In an effort to resist the delegitimization of their amorous experiences, to refuse the image of an inaptitude for profound and stable relationships, lesbians, gays, and bisexuals often distance themselves from polyamory in order to avoid a 'double' stigma.

In this way, the polyamorist agenda's struggle for sexual-affective multiplicity and the deconstruction of monogamous marriage can be seen to be a mostly heterosexual concern - one, that is, created by those who have always had the privilege of monogamous marriage. As Bornia Junior (2018) recognizes, for non-heterosexual people these issues are less relevant in the organization of identity. This may explain the smaller number of lesbians and gays in non-monogamous groups when compared to heterosexual men and bisexual women (Pilão, 2012; Silvério, 2018). There thus seems to be a distance and a lack of compass between non-heterosexuals and the non-monogamous scene, either because non-heterosexuals prefer to emphasise their capacity to be monogamous, or because they do not feel welcome in non-monogamous circles (Bornia Junior, 2018).

Although the political discourse of non-monogamous activism in Brazil is critical of heteronormativity (Barbosa, 2011; Pilão, 2015; Silvério, 2018; Bornia Junior, 2018), there is a perception that their groups are dominated by heterosexual men. As the questioning of male sexuality is a constant theme of LGBT groups, it is difficult to see polyamory as safe and non-oppressive, particularly for women. Fear of masculinity and its refusal (particularly cis in opposition to trans), is expressed by lesbians in their rejection of relationships with bisexual women, since the latter maintain relationships with men. Among bisexuals, this refusal is evident for those who allow open relationships with women, but not with men. 
It is even present among gays who affirm that men are promiscuous and incapable of love. All these views share an image of cis men as obstacles to the construction of long-lasting, profound, and responsible affective relationships. Practicing activism and being in a relationship with them thus poses a huge challenge.

Finally, I stress that even if polyamory and other forms of non-monogamy have influenced LGBT groups, raising questions about what type of relationships can be adopted, influence seems to flow more in the opposite direction. Thus, the greater visibility polyamory acquired in recent years has repercussions in multiplying formulations and evaluations coming from LGBT groups. This fed back into the non-monogamous movement, leading to self-reflections on the perpetuations of sexual and gender oppressions.

Translated by Luiz Costa

Submitted: August 08, 2020

Approved: February 02, 2021

* Research funded by the Conselho Nacional de Desenvolvimento Científico e Tecnológico - (PDJ-CNPq) and the Coordenação de Aperfeiçoamento de Pessoal de Nível Superior (PDSE-CAPES). 


\section{Bibliography}

AVIRAM, Hadar; LEACHMAN, Gwendolyn. 2015. "The Future of Polyamorous Marriage: Lessons from the Marriage Equality Struggle”. Harvard Journal of Law and Gender, UC Hastings Research Paper No. 118.

BARBOSA, Mônica. 2011. Movimentos de resistência à monogamia compulsória. A luta por direitos sexuais e afetivos no século XXI. Dissertação de Mestrado, Desenvolvimento e Gestão Social, UFBA.

BORNIA JUNIOR, Dardo Lorenzo. 2018. Amar é verbo, não pronome possessivo: etnografia das relações nãomonogâmicas no sul do Brasil. Tese de doutorado, Antropologia, UFRGS.

BOURDIEU, Pierre. 1994. "Esboço de uma teoria da prática”. In: Renato Ortiz (org.), Pierre Bourdieu: sociologia. São Paulo: Ática. pp. 46-81.

BOWLER, Gary. 2010. "Netnography: A Method Specifically Designed to Study Cultures and Communities Online”. The Qualitative Report, 15(5): 1270-1275.

BUTLER, Judith. 2003. "O parentesco é sempre tido como heterossexual?” Cadernos Pagu, 21: 219-260.

CARDOSO, Daniel. 2010. Amando vári@s - Individualização, redes, ética e poliamor. Dissertação de mestrado, Ciências da comunicação, Universidade Nova de Lisboa.

. 2014. "My Spivak is bigger than yours: (Mis-)representations of polyamory in the Portuguese LGBT movement and mononormative rhetorics". LES Online, 6(1): 45-64.

CARRARA, Sérgio. 2015. "Moralidades, racionalidades e políticas sexuais no Brasil contemporâneo." Mana, 21(2): 323-335. [https://doi.org/10.1590/0104-93132015v21n2p323 - acessed on May 17, 2020].

CARVALHO, Tâmara. 1995. Caminhos do desejo: Uma abordagem antropológica das relações homoeróticas femininas em Belo Horizonte. Dissertação de Mestrado, Antropologia, UNICAMP.

CATANIA, Joseph; BINSON, Diane; DOLCINI, Margaret; POLLACK, Lance. 1993. "Multiple Sexual Partners Among Young Adults in High-Risk Cities". Family Planning Perspectives, 25(6): 268-272.

CAVALCANTI, Cristina. 1995. "The Glamourisation of Safer Sex in Three Women's Magazines in Brazil”. Reproductive Health Matters, 3(5): 47-53.

COLLING, Leandro. 2015. Que os outros sejam o normal: tensões entre o movimento LGBT e o ativismo queer. Salvador: Editora da Universidade Federal da Bahia.

FACCHINI, Regina; DANILIAUSKAS, Marcelo; PILON, Ana Cláudia. 2013. "Políticas sexuais e produção de conhecimento no Brasil: situando estudos sobre sexualidade e suas conexões". Revista Brasileira de Ciências Sociais, 44(1): 161-193.

FACCHINI, Regina. 2004. "Bissexualidade em movimento" [Post do Blog Espaço B]. Recuperado de http:/ blog-espaco-b.blogspot.com.br/2010/06/bissexualidade-em-movimento-agostode.html.

FOUCAULT, Michel. 1976. Histoire de la Sexualité I: la Volonte dé Savoir. Paris: Gallimard.

FRY, Peter; MACRAE, Edward. 1983. O que é homossexualidade? São Paulo: Brasiliense.

FURSTENBERG, Frank. 1994. "History and Current Status of Divorce in the United States". The Future of Children, 4(1): 29-43.

GREGORI, Maria Filomena. 2003. "Relações de violência e erotismo". Cad. Pagu, 20: 87-120 [https://doi. org/10.1590/S0104-83332003000100003 - accessed on May 17, 2020].

HEILBORN, Maria Luiza. 1992. "Vida a Dois: Conjugalidade Igualitária e Identidade Sexual". In: Anais do VIII Encontro Nacional de Estudos Populacionais - vol. 2. São Paulo, Associação Brasileira de Estudos Populacionais - ABEP. pp. 143-156.

. 2004. Dois é par: gênero e identidade sexual em contexto igualitário. Rio de Janeiro: Garamond.

HERDT, Gilbert et al. 1990. "AIDS on the Planet: The Plural Voices of Anthropology". Anthropology Today, 6(3): 10-15.

JAEGER, Melissa et al. 2019. "Bissexualidade, bifobia e monossexismo: problematizando enquadramentos". Revista Periódicus, 2(11): 1-18. 
KLESSE, Christian. 2006. "Polyamory and its 'others': contesting the terms of non-monogamy”. Sexualities, 9(5) : 565-583. [https:/|journals.sagepub.com/doi/10.1177/1363460706069986-acesso em 17 mai 2020].

KOZINETS, Robert. 2010. Netnography. Doing Ethnographic Research Online. Thousand Oaks, California: Sage Publications.

LATOUR, Bruno. 200o. Ciência em ação: como seguir cientistas e engenheiros sociedade afora. São Paulo: UNESP.

LEWIN, Ellen. 1998. Recognizing Ourselves: Ceremonies of Lesbian and Gay Commitment. New York: Columbia University Press.

. 2002. "Another Unhappy Marriage? Feminist Anthropology and Lesbian/Gay Studies." In: Ellen Lewin and William Leap (orgs.), Out in Theory: The Emergence of Lesbian and Gay Anthropology. Urbana: University of Illinois Press. pp. 110-127.

LEWIS, Elisabeth Sara. 2012. "Não é uma fase": construções identitárias em narrativas de ativistas LGBT que se identificam como bissexuais. Dissertação de mestrado, Letras, PUC.

LOE, Meika. 1998. "The production of sexuality at a pro-sex feminist sex toy store". Berkeley Journal of Sociology, 43: 97-136.

MISKOLCI, Richard. 2007. "Pânicos morais e controle social - reflexões sobre o casamento gay". Cadernos Pagu, 28: 101-128, [https://doi.org/10.1590/So104-83332007000100006, acesso em 17 mai 2020].

MUNIZ, Jacqueline. 1992. Mulher com Mulher dá Jacaré: Uma Abordagem Antropológica da Homossexualidade Feminina. Dissertação de Mestrado, Antropologia, UFRJ.

PAGE, Emily. 2004. "Mental Health Services Experiences of Bisexual Women and Bisexual Men: an Empirical Study". The Journal of Bisexuality, 4(1, 2): 137-16o. [https:/|www.tandfonline.com/doi/abs/10.1300/ J159vo4no1_11, acesso em 17 mai 2020].

PILÃO, Antonio Cerdeira; GOLDENBERG, Mirian. 2012. "Poliamor e monogamia: construindo diferenças e hierarquias. Revista Ártemis, 13: 61-73.

PILÃO, Antonio Cerdeira. 2012. "Poliamor e bissexualidade: idealizando desvios". In: Anais do 360 ENCONTRO ANUAL DA ANPOCS. Mimeo.

. 2013. "Reflexões sócio-antropológicas sobre Poliamor e amor romântico". RBSE - Revista Brasileira de Sociologia da Emoção, 12(35): 505-524.

. 2015. "Entre a liberdade e a igualdade: princípios e impasses da ideologia poliamorista". Cadernos Pagu, 44: 391-422.

. 2017. "Por que Somente um Amor?”: um estudo sobre poliamor e relações não-monogâmicas no Brasil. Tese de doutorado em Sociologia e Antropologia, Rio de Janeiro, UFRJ.

. 2020. "Direitos em disputa: a controvérsia monogamia/poliamor no sistema jurídico brasileiro". In: Anais do 44 ENCONTRO ANUAL DA ANPOCS, Mimeo.

PORTO, Duína. 2018. "Mononormatividade, intimidade e cidadania”. Rev. Direito GV [online], 14(2): 654-681.

RITCHIE, Ani; BARKER, Meg. 2007. “'Hot Bi Babes' and Feminist Families: Polyamorous women speak out". Lesbian and Gay Psychology Review, 8(2): 141-151. [http:/|oro.open.ac.uk/17251/, accessed on May 17, 2020].

RUBIN, Gayle. 1984. “Thinking Sex: Notes for a Radical Theory of the Politics of Sexuality”. In: Carole Vance (ed.), Pleasure and Danger: Exploring Female Sexuality. Nova York: Routledge. pp. 267-319.

RUST, Paula. 1996. "Monogamy and Polyamory: Relationship Issues for Bisexuals”. In: Beth Firestein (ed.), Bisexuality: The psychology \& politics of an invisible minority. Thousand Oaks, CA: Sage. pp. 127-148.

SAHLINS, Marshall. 2008. Metáforas históricas e realidades míticas: estrutura nos primórdios da história do reino das Ilhas Sandwich. Rio de Janeiro: Jorge Zahar Ed.

SANTIAGO SILVA, Rafael. 2014. O mito da monogamia à luz do direito civil-constitucional: a necessidade de uma proteção normativa às relações de poliamor. Dissertação de mestrado em Direito, Brasília, UNB. 
SEIDMAN, Steven. 2001. "From Identity to Queer Politics: Shifts in the Social Logic of Normative Heterosexuality in Contemporary America”. Social Thought \& Research, 24(1/2): 1-12.

SHEFF, Elisabeth. 2005. "Polyamorous Women, Sexual Subjectivity and Power". Journal of Contemporary Ethnography, 34(3): 251-283. [https://doi/10.1177/0891241604274263- acesso17 mai 2020].

SIMPSON, Bob. 1994. "Bringing the 'Unclear' Family Into Focus: Divorce and Re-Marriage in Contemporary Britain". Man New Series, 29(4): 831-851.

SIMÕES, Júlio; CARRARA, Sérgio. 2014. "O campo de estudos socioantropológicos sobre diversidade sexual e de gênero no Brasil: ensaio sobre sujeitos, temas e abordagens.” Cad. Pagu, 42: 75-98. [https://doi. org/10.1590/0104-8333201400420075, acesso em 17 mai 2020].

SILVÉRIO, Maria Silva. 2018. Eu, tu... ilus: poliamor e não-monogamias consensuais. Tese de doutorado, Antropologia, ISCTE-IUL.

TOLEDO, Lívia; FILHO, Fernando. 2012. "As lesbianidades entre o estigma da promiscuidade e da ilegitimidade sexual”. Temáticas, 20(40): 67-103. [https:/|www.ifch.unicamp.br/ojs/index.php/tematicas| article/view/2206, acesso em 17 mai 2020].

VALE DE ALMEIDA, Miguel. 2006. "O casamento entre pessoas do mesmo sexo. Sobre 'gentes remotas e estranhas' numa "'sociedade decente", Revista Crítica de Ciências Sociais, 76: 17-31.

VAZ DA SILVA, Vania. 2017. "Estudos acadêmicos sobre o Poliamor”. Revista Tempo da Ciência, 24(48), Cascavel, Unioeste. [http://e-revista.unioeste.br/index.php/tempodaciencia/article/view/18968-acesso em 17 mai 2020].

VEAUX, Franklin; RICKERT, Eve. 2014. More Than Two: A Practical Guide to Ethical Polyamory. Portland: Thorn Tree Press.

VENCATO, Anna Paula. 2005. “Algumas garotas preferem garotas': The L Word, sexualidade e as políticas de visibilidade lésbica". Anais da Reunião de Antropologia do Mercosul, 6, Montevideo, pp. 52-61. Mimeo.

WEEKS, Jeffrey. 1989. Sex, Politics and Society: the Regulation of Sexuality since 180o. Londres: Longman.

WOSICK-CORREA, Kassia. 2010. "Agreements, Rules, and Agentic Fidelity in Polyamorous

Relationships". Psychology and Sexuality, 1: 44-61. [https://www.tandfonline.com/doi/

abs/10.1080/19419891003634471, acesso em 17.05.2020].

\author{
Antonio Cerdeira Pilão \\ University of São Paulo, Graduate Programme in Anthropology (PPGAS-USP), São Paulo/SP, Brazil. \\ https://orcid.org/0000-0002-3966-5531 \\ Email: pilao@usp.br; tonipilao@gmail.com
}

